
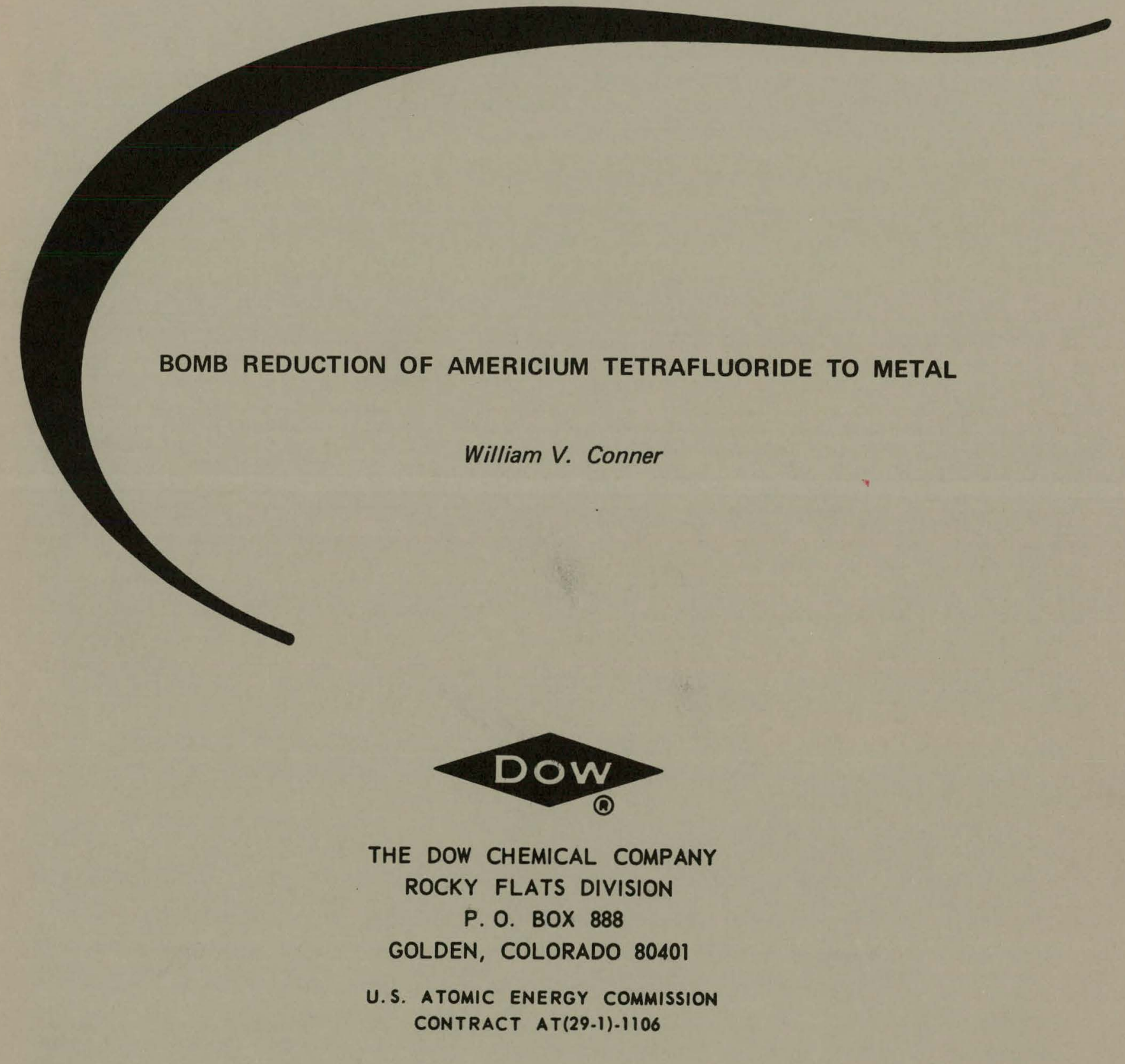

William V. Conner

THE DOW CHEMICAL COMPANY ROCKY FLATS DIVISION

P. O. BOX 888

GOLDEN, COLORADO 80401

U.S. ATOMIC ENERGY COMMISSION CONTRACT AT(29-1)-1106

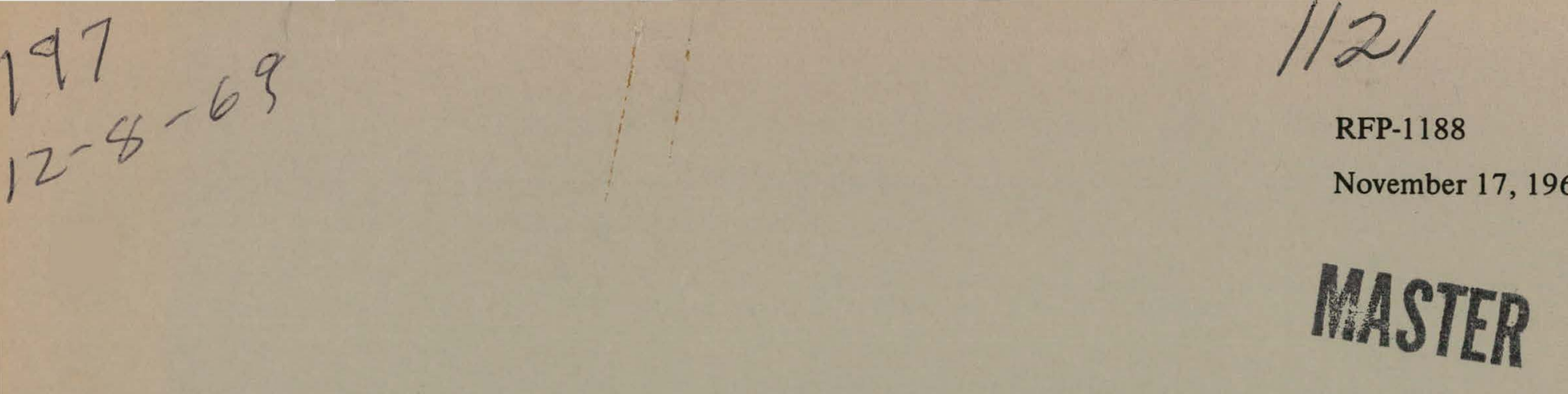

$1 / 21$

RFP-1188

November 17, 1969

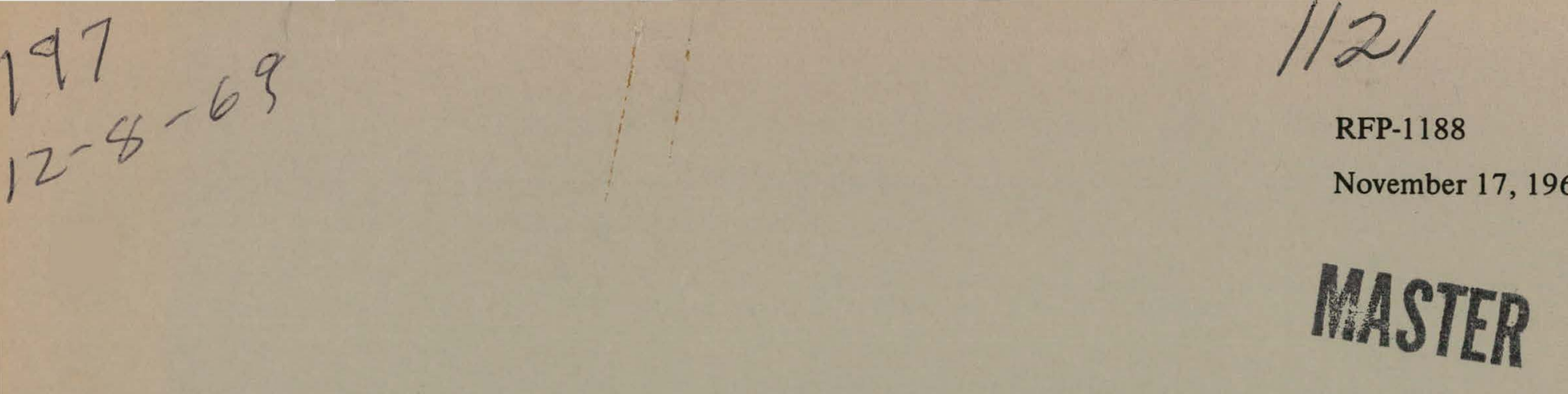

BOMB REDUCTION OF AMERICIUM TETRAFLUORIDE TO METAL
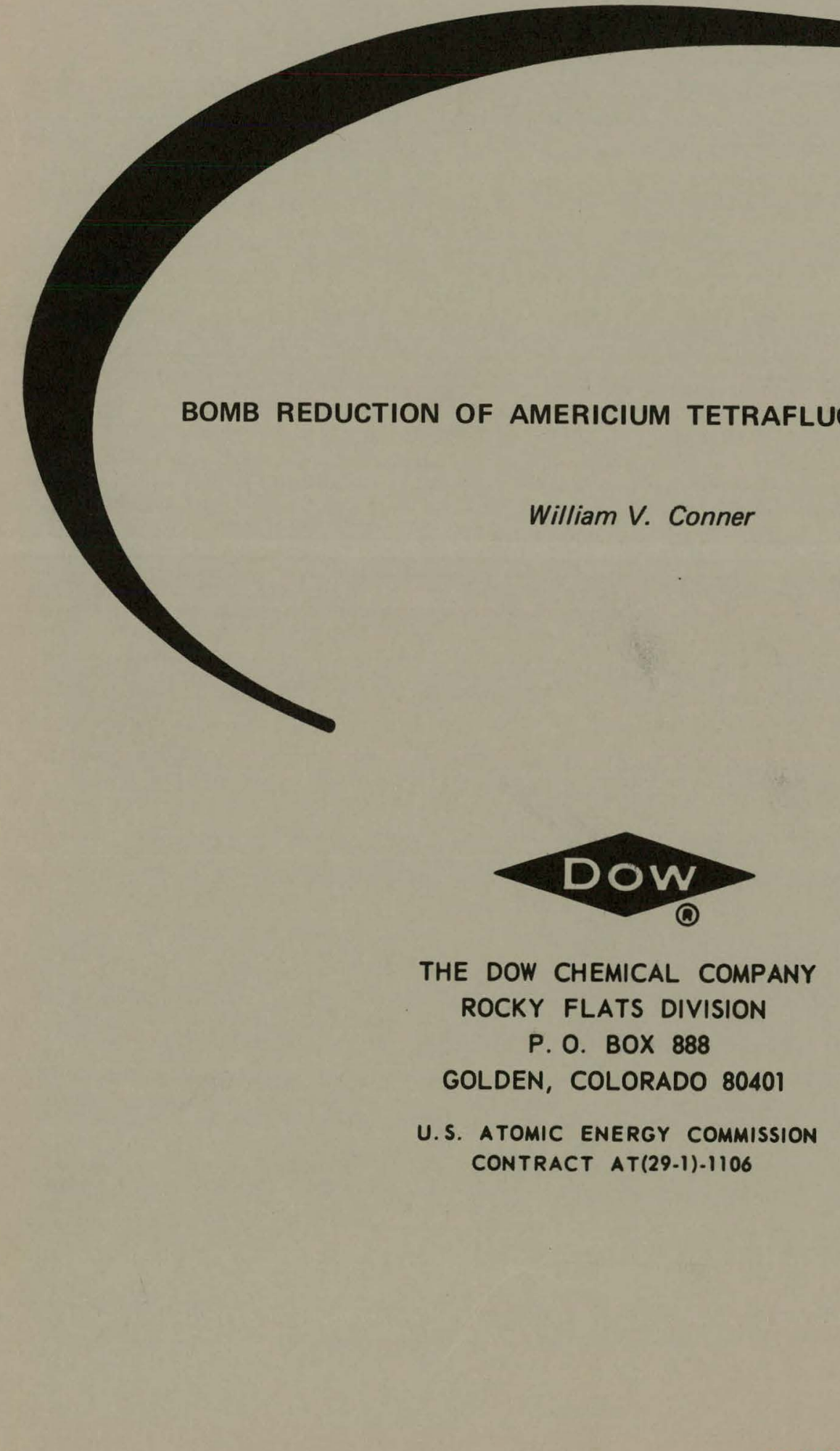


\section{DISCLAIMER}

This report was prepared as an account of work sponsored by an agency of the United States Government. Neither the United States Government nor any agency Thereof, nor any of their employees, makes any warranty, express or implied, or assumes any legal liability or responsibility for the accuracy, completeness, or usefulness of any information, apparatus, product, or process disclosed, or represents that its use would not infringe privately owned rights. Reference herein to any specific commercial product, process, or service by trade name, trademark, manufacturer, or otherwise does not necessarily constitute or imply its endorsement, recommendation, or favoring by the United States Government or any agency thereof. The views and opinions of authors expressed herein do not necessarily state or reflect those of the United States Government or any agency thereof. 


\section{DISCLAIMER}

Portions of this document may be illegible in electronic image products. Images are produced from the best available original document. 


\section{LEGAL NOTICE}

This report was prepared as an account of Government sponsored work. Neither the United States, nor the Atomic Energy Commission, nor any person acting on behalf of the Commission:

A. Makes any warranty or representation, expressed or implied, with respect to the accuracy, completeness, or usefulness of the information contained in this report, or that the use of any information, apparatus, method, or process disclosed in this report may not infringe privately owned rights; or

B. Assumes any liabilities with respect to the use of, or for damages resulting from the use of any information, apparatus, method, or process disclosed in this report.

As used in the above, "person acting on behalf of the Commission" includes any employee or contractor of the Commission, or employee of such contractor, to the extent that such employee or contractor of the Commission, or employee of such contractor prepares, disseminates, or provides access to, any information pursuant to his employment or contract with the Commission, or his employment with such contractor.

Printed in the United States of America Available from

Clearinghouse for Federal Scientific and Technical Information National Bureau of Standards, U. S. Department of Commerce

Springfield, Virginia 22151

Price: Printed Copy $\$ 3.00$; Microfiche $\$ 0.65$ 


\title{
BOMB REDUCTION OF AMERICIUM TETRAFLUORIDE TO METAL
}

\author{
William V. Conner
}

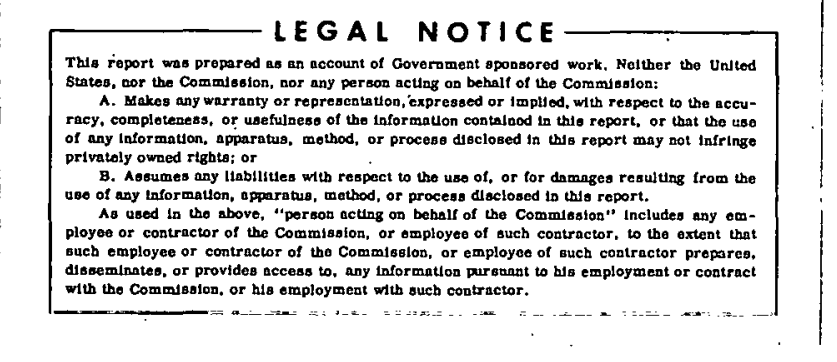

\footnotetext{
THE DOW CHEMICAL COMPANY

ROCKY FLATS DIVISION

P. O. BOX 888

GOLDEN, COLORADO 80401

Prepared under Controct AT(29-1)-1106

for the

Albuquerque Operations Office

U. S. Atomic Energy Commission
} 
RFP-1 188 


\section{CONTENTS}

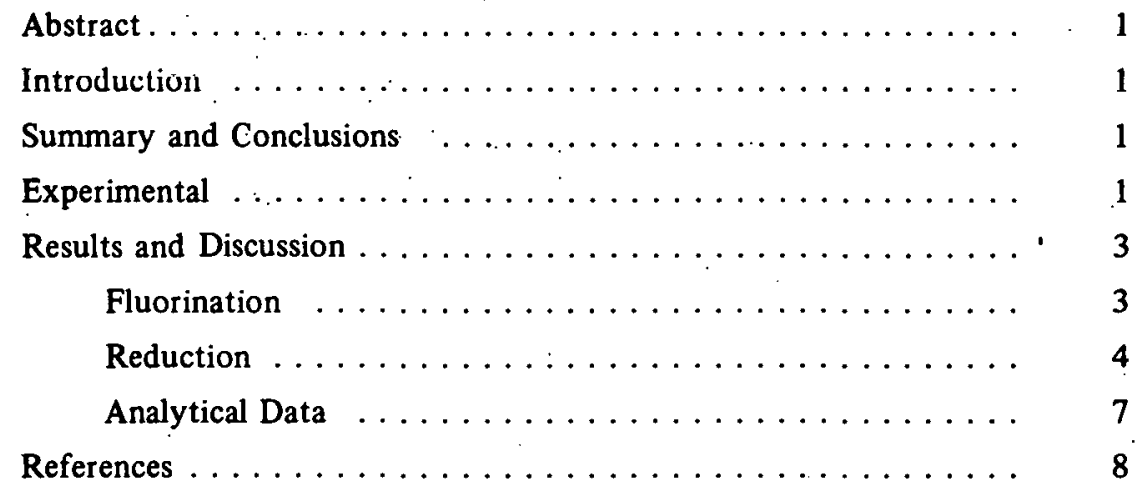


RFP-1 188

\section{ACKNOWLEDGMENTS}

The author wishes to thank J. W. Fergusun for x-ray diffraction analysis of the $\mathrm{AmF}_{4}$, and $\mathrm{B}$. J. Beer and D. L. Marts for hardness and density measurements on thc americium metal. Spectrographic analysis of the $\mathrm{AmO}_{2}$ and americium metal were performed by the Plutonium Analytical Laboratories. 
RFP-1188

\title{
BOMB REDUCTION OF $\mathrm{AmF}_{4}$ TO METAL
}

\author{
William V. Conner
}

\begin{abstract}
Americium metal was prepared on a gram scale using the thermite bomb method. The metal was prepared by converting $\mathrm{AmO}_{2}$ to $\mathrm{AmF}_{4}$ with fluorine and reducing the $\mathrm{AmF}_{4}$ with calcium metal. Reduction yields of 34 to $64 \%$ were obtained.
\end{abstract}

\section{INTRODUCTION}

Americium metal was first prepared in gram quantities by Johnson and Leary ${ }^{1}$ by heating a mixture of $\mathrm{AmO}_{2}$ and $\mathrm{La}$ metal in high vacuum and collecting Am metal as the distillate. Prior to using this procedure, they attempted to use the bomb method by heating $\mathrm{AmF}_{3}$ and $\mathrm{Ba}$ in a sealed bomb, without success. The $\mathrm{La}$ reduction of $\mathrm{AmO}_{2}$ has been used by other workers ${ }^{2,3}$ to prepare multigram quantities of high purity Am metal.

The La reduction method required equipment capable of obtaining operating temperatures in the range of $1500^{\circ}$ to $1600^{\circ} \mathrm{C}$ and a high vacuum system. This equipment was expensive and was not readily available. The equipment required for the thermite bomb method was inexpensive and was readily obtainable. The process chosen for investigation involved the conversion of $\mathrm{AmO}_{2}$ to $\mathrm{AmF}_{4}$ with fluorine, followed by bomb reduction of the $\mathrm{AmF}_{4}$ with calcium.

The work described in this report was of a preliminary nature and additional work will be required to optimize the bomb reduction process for americium. Future plans include comparing the economic and technical aspects of the bomb reduction and $\mathrm{La}$ distillation processes.

\section{SUMMARY AND CONCLUSIONS}

A procedure was developed for preparing gram quantities of americium metal using the thermite bomb method. The americium metal was prepared by converting $\mathrm{AmO}_{2}$ to $\mathrm{AmF}_{4}$ with fluorine and reducing the $\mathrm{AmF}_{4}$ to metal with calcium. The equipment required for the fluorination step consisted of bottled fluorine, a nickel fluorination boat, a Monel fluorination reactor, and Monel fluorine disposal traps filled with charcoal. A hot plate was used to heat the reactor. The reduction equipment consisted of a tantaum or $\mathrm{MgO}$ crucible and lid, and a stainless steel pressure vessel and lid. The reduction vessel was heated in a vertical crucible furnace.
The $\mathrm{AmO}_{2}$ was converted to $\mathrm{AmF}_{4}$ using starting temperatures of $250^{\circ}$ to $300^{\circ} \mathrm{C}$. Three 10-to-20-gram batches of oxide were processed using fluorination times of 50 to 55 minutes, and $100 \%$ conversion to $\mathrm{AmF}_{4}$ was achieved for all three batches. Neutron flux and temperature measurements indicated that the conversion to $\mathrm{AmF}_{4}$ may have been complete in 15 to 30 minutes.

The $\mathrm{AmF}_{4}$ was reduced to metal in four batches using a $30 \%$ excess of $\mathrm{Ca}$ and 0.75 to 1 mole of $I_{2}$ per mole of americium. Americium metal was produced in all four reductions. The yields varied from 34 to $64 \%$.

The thermite bomb method offers an inexpensive means for producing Am metal. With additional development it should be possible to improve reduction yields. By starting with pure $\mathrm{AmO}_{2}$, metal of greater than $99.9 \%$ purity should be expected.

\section{EXPERIMENTAL}

Americium-241 is an alpha emitter with a 433 year halflife. ${ }^{4}$ When experimenting with $\mathrm{Am}$ metal, $\mathrm{AmO}_{2}$, or $\mathrm{AmF}_{4}$, precautions must be taken to protect the worker against the $60-\mathrm{keV}$ gamma radiation associated with the nuclide, and the neutron radiation from the alpha-neutron reaction associated with $\mathrm{AmO}_{2}$ and $\mathrm{AmF}_{4}$. For this reason, the work described in this report was performed in a watershielded hot cell. The cell consists of an alpha-containment glovebox surrounded by 1 -foot-thick water walls. (See Figure 1.) The operating side of the cell is equipped with two Central Research Laboratory Model-7 master slave manipulators. The maintenance side of the glovebox is equipped with 30-mil lead-loaded neoprene gloves.

The fluorination reactor, $F_{2}$ supply and exhaust lines, and $F_{2}$ disposal traps are shown in Figure 2. The reactor body and lid were Monel. The lid contained a thermocouple well which extended to within one-quarter inch of the material to be fluorinated. A stainless steel O-ring was used to seal the reactor. Flexible lines of Teflon tubing covered with stainless-steel braid were used to connect the reactor to the $F_{2}$ supply and exhaust lines. The $F_{2}$ exhaust line led to Monel disposal traps which were filled with charcoal. While fluorinating, the pressure in the $F_{2}$ supply line was maintained at $6 \mathrm{psig}$ and the disposal traps were vented to the glovebox atmosphere. The reactor was heated with a hot plate. 


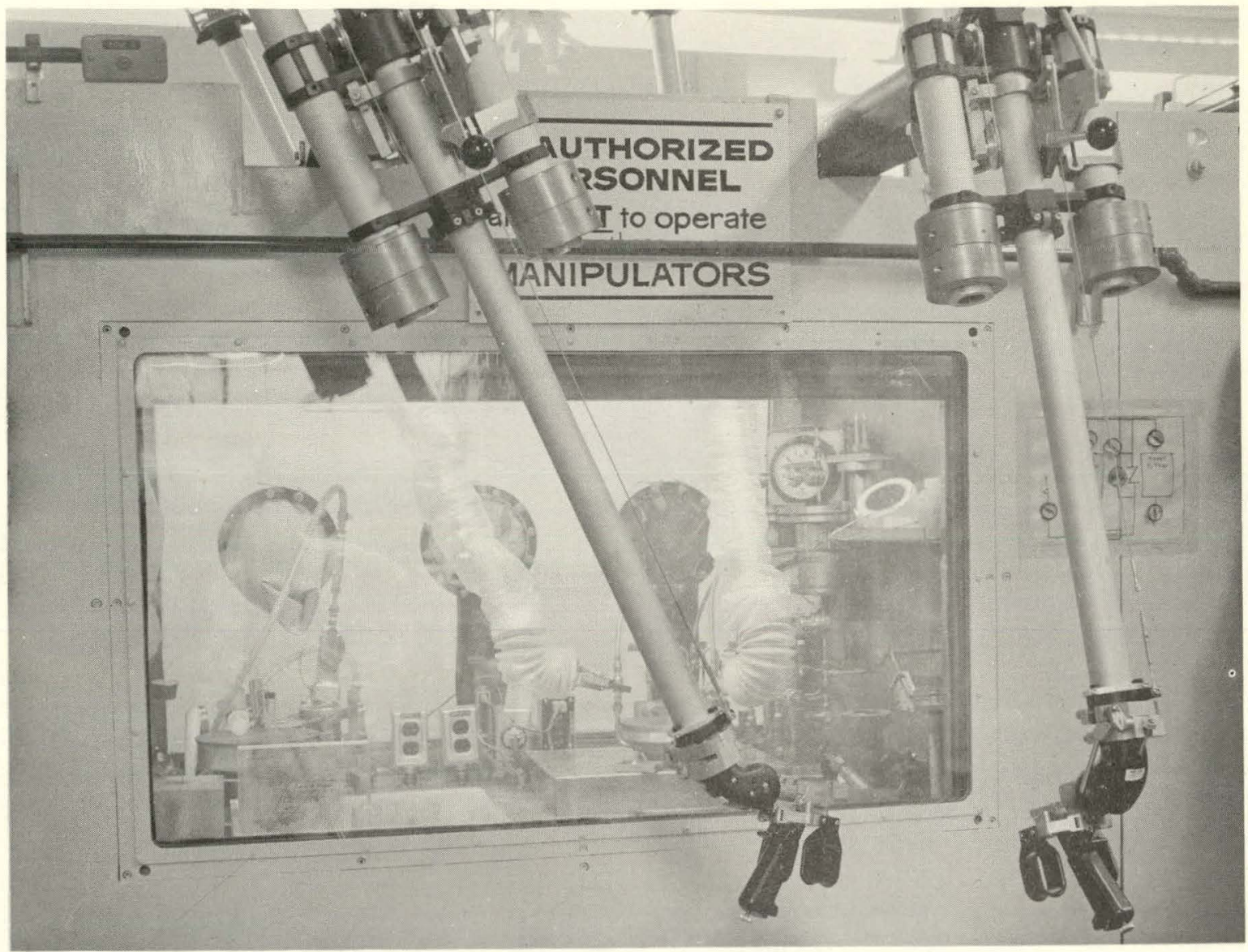

Figure 1. Water-shielded hot cell.

The $\mathrm{AmO}_{2}$ was placed in a nickel fluorination boat and the boat was placed in the reactor. The reactor was evacuated, checked for leaks, and filled with argon. When the reactor had reached the desired temperature, fluorine gas was introduced. A short time after the $\mathrm{F}_{2}$ was introduced, the temperature began to increase. The increase in temperature was caused by the exothermic reaction between $\mathrm{AmO}_{2}$ and $\mathrm{F}_{2}$. The occurrence of this temperature increase was an indication that the reaction was occurring. The rate at which the temperature increased was an indication of how well the reaction was proceeding. After a predetermined length of time, the fluorine flow was turned off and the system allowed to cool.

The reduction vessels consisted of a $\mathrm{MgO}$ or tantalum crucible and a stainless-steel pressure vessel with a stainless steel lid. (See Figure 3.) The crucible was placed in the pressure vessel and the annulus between the crucible and pressure vessel was filled with $\mathrm{MgO}$ sand. A copper gasket was used to seal the pressure vessel.

The reduction charges contained a 30 mole \% excess of $\mathrm{Ca}^{*}$ and 0.75 to 1.0 mole of $\mathrm{I}_{2} / \mathrm{mole}$ of americium. The charges were loaded in the crucible by mixing $10 \mathrm{wt} \%$ of the $\mathrm{I}_{2}$ with $10 \mathrm{wt} \%$ of the $\mathrm{Ca}$ and placing this mixture in the hottom of the crucihle. The $A_{m F}$ was mixed with $80 \%$ of the $\mathrm{I}_{2}$ and $80 \%$ of the $\mathrm{Ca}$ and this mixture was added to the crucible. The remaining $10 \%$ of the $\mathrm{I}_{2}$ and $\mathrm{Ca}$ was then added to the crucible. The lid was bolted on the reaction vessel and the vessel was purged with argon and checked for leaks. The vessel was then placed in a vertical crucible furnace which had been heated to $950^{\circ} \mathrm{C}$. After the charge reacted, as determined by a decrease in the neutron flux, the vessel was removed from the furnace and allowed to cool.

*The excess of calcium is the amount of calcium in excess of that required stoichiometrically to react with all the $\mathrm{AmF}_{\mathbf{4}}$ and $\mathrm{I}_{2}$ in the charge. 


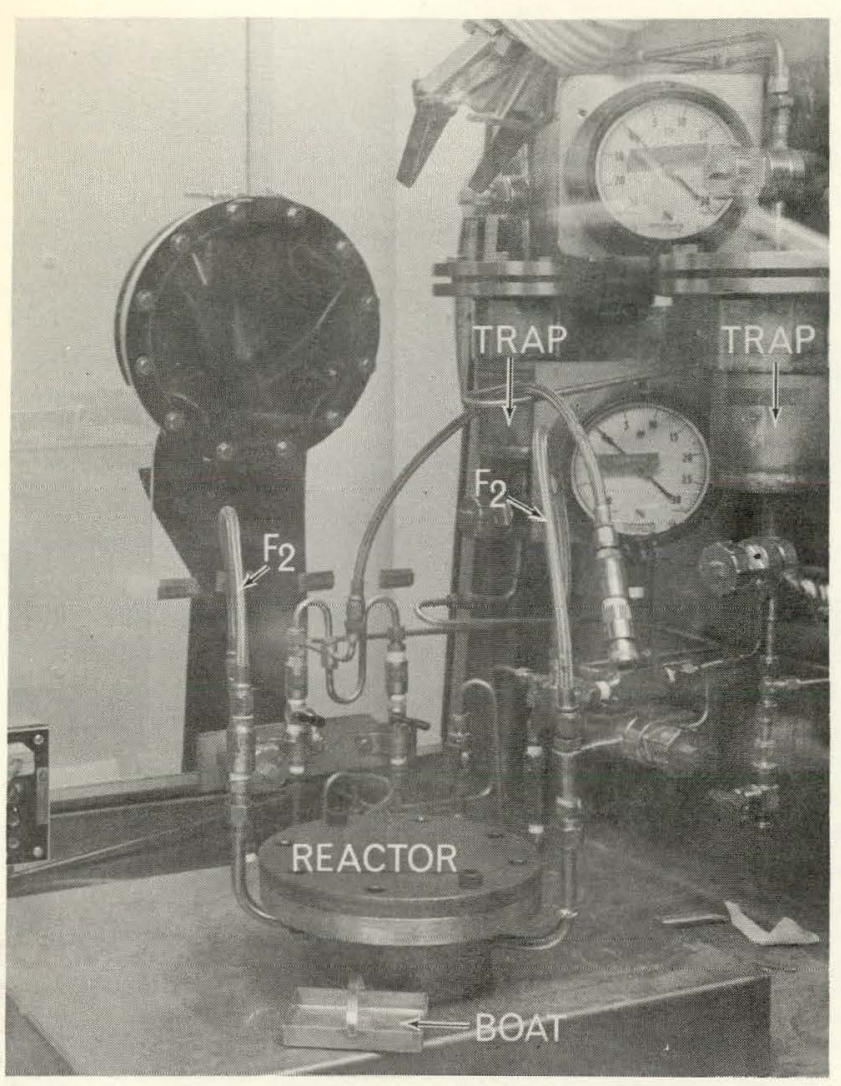

Figure 2. Nickel fluorination boat, Monel reactor, fluorine lines, and disposal traps.

\section{RESULTS AND DISCUSSION}

The $\mathrm{AmO}_{2}$ used for this work was obtained from the $\mathrm{AmO}_{2}$ production line at Rocky Flats. The oxide contained from 1.5 to $2.5 \%$ impurities and was used without any further purification.

Fluorination: The literature indicated that $\mathrm{AmF}_{4}$ could be prepared by reacting $\mathrm{AmO}_{2}$ with fluorine at $500^{\circ} \mathrm{C}$ and 1 atm pressure. ${ }^{5}$ Since $\mathrm{PuO}_{2}$ can be converted to $\mathrm{PuF}_{4}$ with $\mathrm{F}_{2}$ at $100^{\circ}$ to $300^{\circ} \mathrm{C},{ }^{6}$ the conversion of the first batch of $\mathrm{AmO}_{2}$ was attempted using a starting temperature of $300^{\circ} \mathrm{C}$. The first batch of $\mathrm{AmO}_{2}$ weighed $22.7 \mathrm{~g}$ and contained $18.86 \mathrm{~g}$ of americium. The oxide was placed in the reactor and $\mathrm{F}_{2}$ was introduced at $200 \mathrm{cc} / \mathrm{min}$ when the temperature reached $300^{\circ} \mathrm{C}$. The temperature began increasing one minute after the $F_{2}$ was introduced. Five minutes later the $\mathrm{F}_{2}$ flow was increased to $400 \mathrm{cc} / \mathrm{min}$. At this time, the temperature was $380^{\circ} \mathrm{C}$. The $\mathrm{F}_{2}$ flow was turned off after 55 minutes of fluorination. A Texas Nuclear neutron dosimeter was used to measure the neutron flux from the alpha-neutron reaction associated with $\mathrm{AmF}_{4}$. The neutron dosimeter was placed approximately 18 inches from the reactor. The neutron flux was
$8 \mathrm{mrem} / \mathrm{hr} 4$ minutes after the $\mathrm{F}_{2}$ was introduced. This had increased to $28 \mathrm{mrem} / \mathrm{hr} 6$ minutes later.

The starting $\mathrm{AmO}_{2}$ was black. When the boat was removed from the reactor, the top layer was tan and the color darkened to brown near the bottom of the boat. The reported color of $\mathrm{AmF}_{4}$ is tan. ${ }^{5}$ The weight gained by the material during fluorination indicated $100 \%$ conversion to $\mathrm{AmF}_{4}$. This was verified using $\mathrm{x}$-ray diffraction techniques. The sample analyzed contained no detectable $\mathrm{AmO}_{2}$ *

The second batch of $\mathrm{AmO}_{2}$ weighed $13.51 \mathrm{~g}$ and was converted using a starting temperature of $250^{\circ} \mathrm{C}$. The $\mathrm{F}_{2}$ was introduced at $200 \mathrm{cc} / \mathrm{min}$ and this was slowly increased to $500 \mathrm{cc} / \mathrm{min}$ during the first 10 minutes of fluorination. The $F_{2}$ was turned off after 50 minutes of fluorination. The neutron flux (see Figure 4) was $2.0 \mathrm{mrem} / \mathrm{hr}$ at 18 inches when the $F_{2}$ was introduced. The flux increased to $15.0 \mathrm{mrem} / \mathrm{hr}$ after 10 minutes of fluorination, and reached a maximum of $16 \mathrm{mrem} / \mathrm{hr}$ after 13 minutes of fluorination. This would indicate that most of the $\mathrm{AmO}_{2}$ was converted during the first 10 to 15 minutes of fluorination.

The $\mathrm{AmF}_{4}$ was again tan in color with some brown spots when viewed through the lead glass and water window in the front of the cell. However, when the material was viewed through the one-half-inch window of Plexiglas on the maintenance side of the glovebox, the light portions were pink and the dark portions were purple. X-ray diffraction analysis showed the product to be $\mathrm{AmF}_{4}$ which contained $<0.2 \% \mathrm{AmO}_{2}$. ${ }^{* *}$ This leaves some doubt as to the true color of $\mathrm{AmF}_{4}$.

A starting temperature of $280^{\circ} \mathrm{C}$ was used for fluorinating the third batch of $\mathrm{AmO}_{2}$. The $\mathrm{F}_{2}$ was introduced at 100 $\mathrm{cc} / \mathrm{min}$. This was increased to $400 \mathrm{cc} / \mathrm{min} 5$ minutes later. The $\mathrm{F}_{2}$ was turned off after 55 minutes. The $\mathrm{AmF}_{4}$ again appeared tan to brown through the lead glass and water window, and pink to purple through the one-halfinch window of Plexiglas. The weight gain indicated a $100 \%$ conversion to $\mathrm{AmF}_{4}$. A summary of the fluorination conditions for all three batches of $\mathrm{AmO}_{2}$ is given in Table I.

The third batch of $\mathrm{AmO}_{2}$ weighed $25.18 \mathrm{~g}$ and the starting neutron flux was $4.2 \mathrm{mrem} / \mathrm{hr}$. This was approximately twice the starting flux observed for the $13.51 \mathrm{~g}$ second batch. This was expected since the neutron flux from the

\footnotetext{
* This sample was covered with a Mylar film. This gave a lower limit of detection for $\mathrm{AmO}_{2}$ of $1 \%$.

**The lower limit of detection was achieved by using a Teflon covering in place of the Mylar used for the first sample.
} 

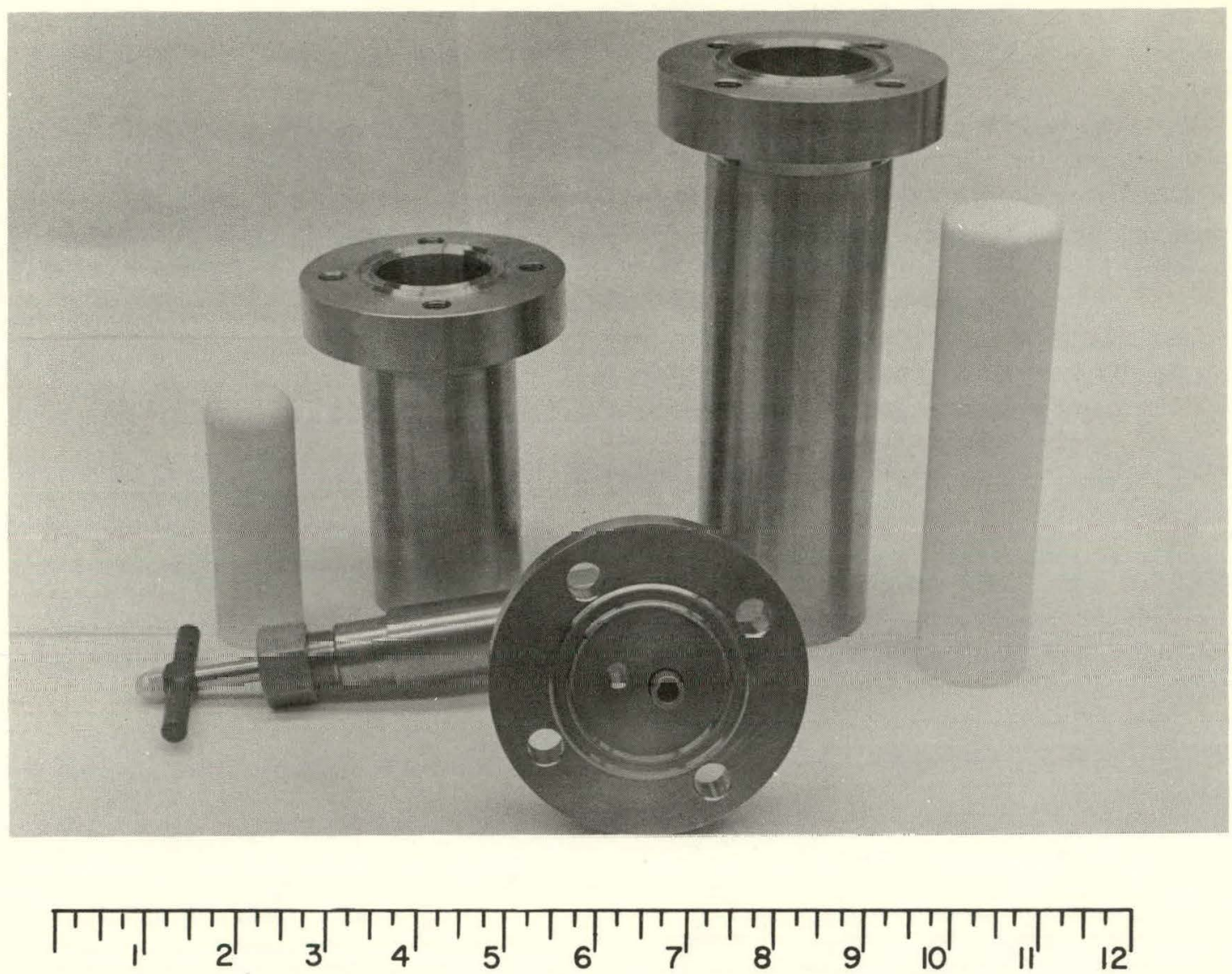

Figure 3. The 15 gram and 50 gram reduction vessels.

alpha-neutron reaction associated with $\mathrm{AmO}_{2}$ should increase in direct proportion to the increase in $\mathrm{AmO}_{2}$. The flux increased to $20 \mathrm{mrem} / \mathrm{hr}$ after 13 minutes of fluorination and reached a maximum of $22 \mathrm{mrem} / \mathrm{hr}$. A plot of neutron flux as a function of time during the fluorination of the second and third batches of $\mathrm{AmO}_{2}$ is shown in Figure 4. This figure shows that most of the $\mathrm{AmO}_{2}$ in both batches appears to have been converted during the first 15 minutes of fluorination.

The temperature curve obtained from the fluorination of the third batch of $\mathrm{AmO}_{2}$ tends to support the neutron flux data (see Figure 5). The temperature increased from $280^{\circ}$ to $440^{\circ} \mathrm{C}$ during the first 14 minutes of fluorination. The temperature then steadily decreased to the temperature of the hot plate.

Reduction: There are two problems which must be overcome if Am metal is to be made successfully using the bomb method. The first is the high vapor pressure of americium ${ }^{7}$ in the liquid state, and the second is the high melting point $\left(994^{\circ} \pm 7^{\circ} \mathrm{C}\right)^{8}$ of Am metal. Sufficient heat must be provided to ensure good metal coalescence. Too much heat, however, will cause excessive vaporization of Am metal. The first reduction charge was prepared in an attempt to ensure good metal coalescence. If Am metal was produced, the vaporization problem could be dealt with in subsequent reductions by changing the ratio of $\mathrm{I}_{2}$ to Am or the size of the charge.

The first reduction was made on a $20 \mathrm{~g}$ scale. The exothermic reaction between $\mathrm{Ca}$ and $\mathrm{I}_{2}$ was used to supply the heat required for good metal coalescence.

$$
\mathrm{Ca}+\mathrm{I}_{2} \rightarrow \mathrm{CaI}_{2} \Delta \mathrm{H}_{298}{ }^{\circ} \mathrm{K}=-128 \mathrm{Kcal} / \mathrm{mole}
$$

The charge contained 1 mole of $\mathrm{I}_{2}$ per mole of Am and was placed in a tantalum metal crucible. A $30 \%$ excess of $\mathrm{Ca}$ was used for all four reductions. The $50 \mathrm{~g}$ scale reduction vessel was purged, and pressurized to 1 psig with argon. The charge reacted 5 minutes after the vessel was placed 
RFP-1188

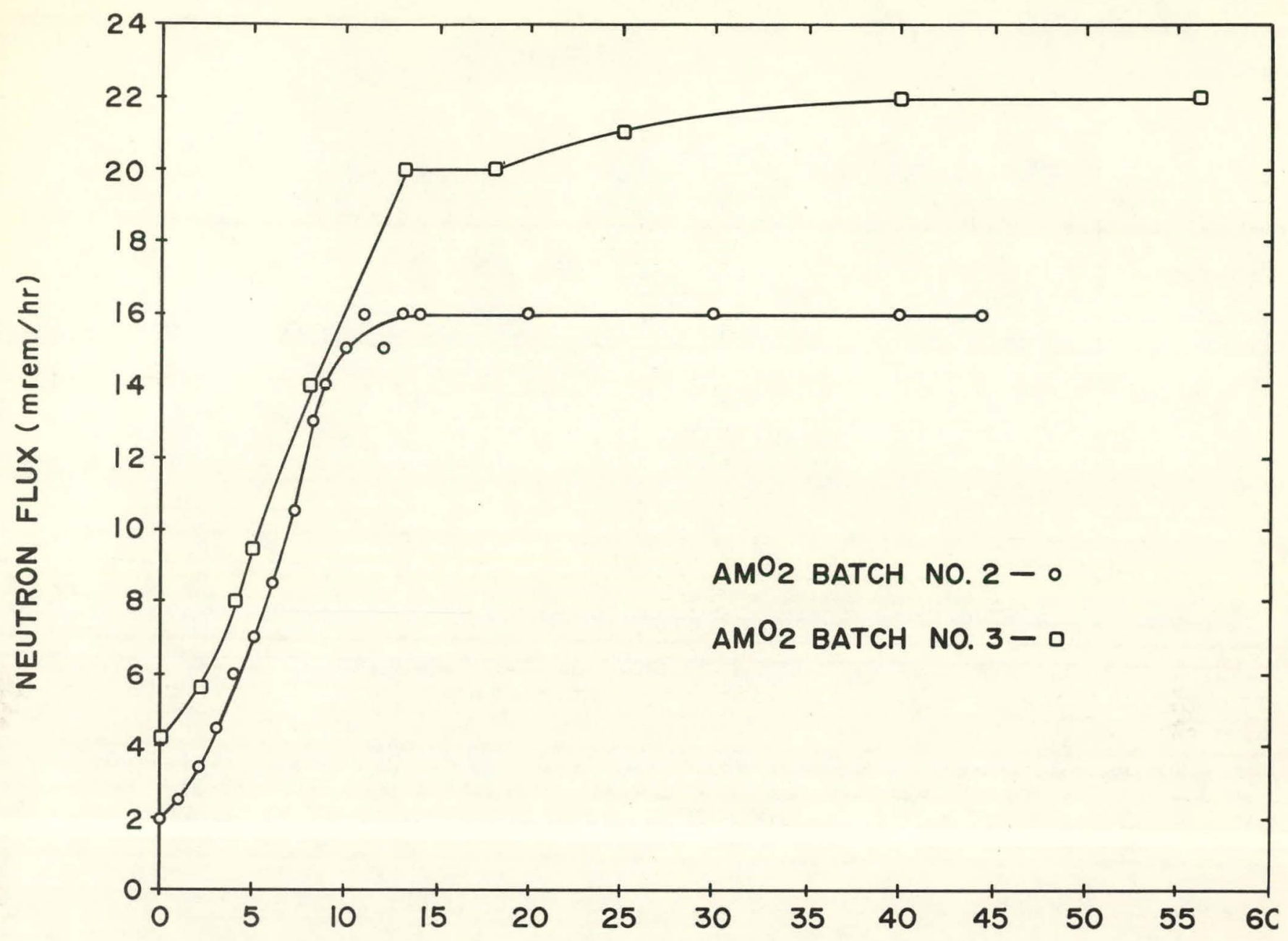

FLUORINATION TIME (minutes)

Figure 4. Neutron flux as function of time during fluorination of $\mathrm{AmO}_{2}$-batches 2 and 3 .

Table I. Operating conditions for the conversion of $\mathrm{AmO}_{2}$ to $\mathrm{AmF}_{4}$.

\begin{tabular}{|c|c|c|c|c|c|c|c|c|}
\hline $\begin{array}{c}\text { Batch } \\
\text { No. }\end{array}$ & $\begin{array}{c}\mathrm{AmO}_{2} \\
\text { Weight } \\
\text { (g) } \\
\end{array}$ & $\begin{array}{c}\mathrm{AmF}_{4} \\
\text { Weight } \\
\text { (g) } \\
\end{array}$ & $\begin{array}{c}\text { Conversion } \\
\text { to } \mathrm{AmF}_{4} \\
(\%)\end{array}$ & $\begin{array}{c}\text { Starting } \\
\text { Temp } \\
\left({ }^{\circ} \mathrm{C}\right)\end{array}$ & $\begin{array}{l}\text { Max Temp } \\
\text { of Heat } \\
\text { Spike } \\
\text { (C) } \\
\end{array}$ & $\begin{array}{c}\text { Starting } \\
\text { Neutron } \\
\text { Flux } \\
(\mathrm{mrem} / \mathrm{hr}) \\
\end{array}$ & $\begin{array}{c}\begin{array}{c}\text { Final } \\
\text { Neutron } \\
\text { Flux } \\
(\mathrm{mrem} / \mathrm{hr})\end{array} \\
\end{array}$ & $\begin{array}{l}\text { Length of } \\
\text { Fluorination } \\
\text { (minutes) }\end{array}$ \\
\hline 1 & 22.70 & 26.41 & 100 & 300 & 410 & * & 28 & 55 \\
\hline 2 & 13.51 & 15.51 & 100 & 250 & 340 & 2.0 & 16.0 & 50 \\
\hline 3 & 25.18 & 29.06 & 100 & 280 & 440 & 4.2 & 22 & 55 \\
\hline
\end{tabular}

*Not obtained. 


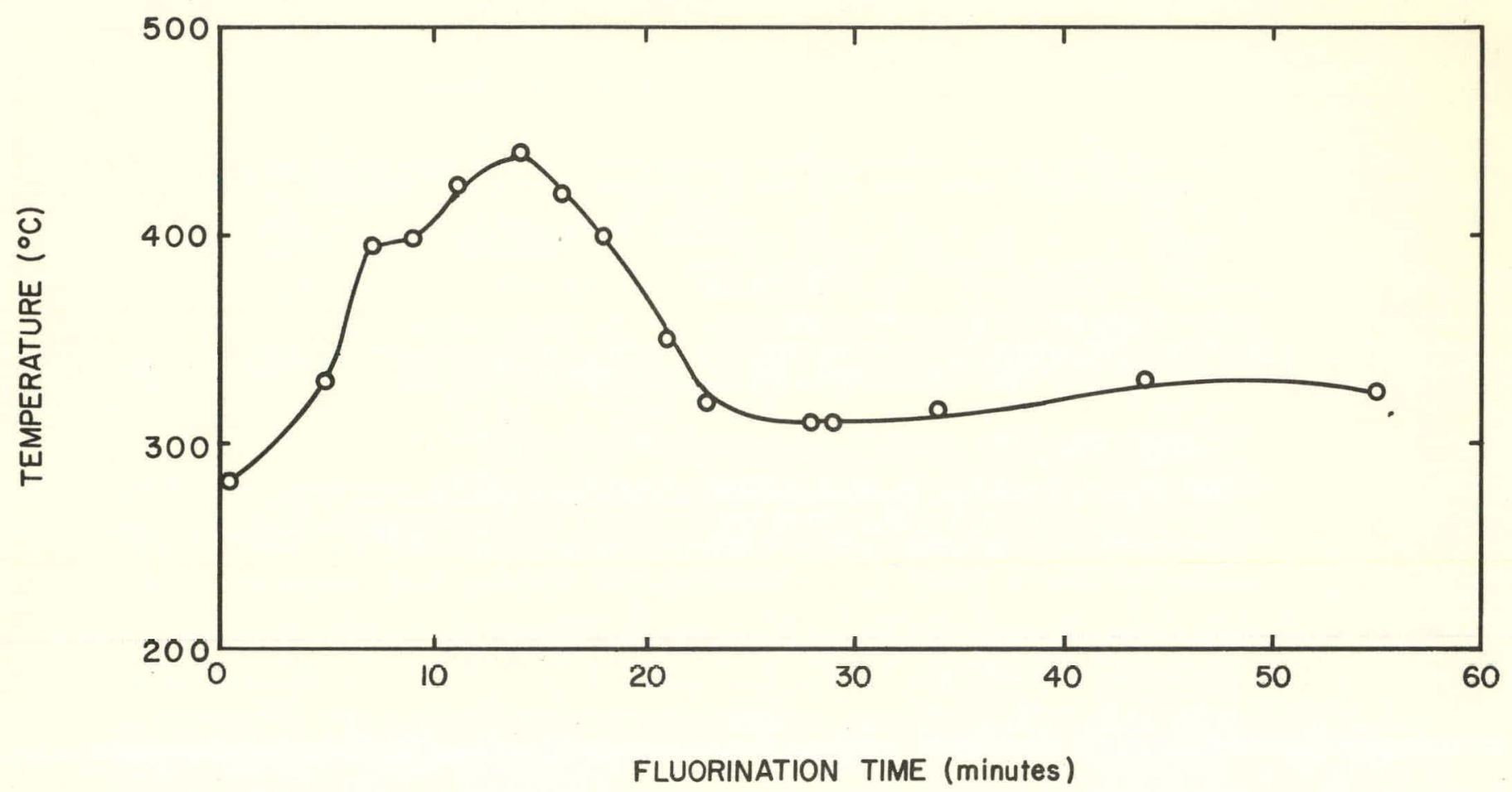

Figure 5. Temperature as a function of time during fluorination of $\mathrm{AmO}_{2}$-batch 3 .

in the furnace, as indicated by a rapid increase in the temperature from $55^{\circ}$ to $380^{\circ} \mathrm{C}$ and a decrease in the neutron flux from 35 to $1.8 \mathrm{mrem} / \mathrm{hr}$.

When the vessel was opened, the pressure vessel lid, thermocouple well, and crucible were coated with a layer of gray material. The small amount of slag still left in the bottom of the crucible was also gray. The Am button was small, but well-formed. The button weighed $6.41 \mathrm{~g}$ for a $34 \%$ yield. The Am vaporization had been extensive, as evidenced by the slag splattering and the amount of Am metal which was found deposited on the under side of the pressure vessel lid.

An attempt was made to reduce the Am vaporization in the second reduction by decreasing the size of the charge and the $\mathrm{I}_{2}$ to Am ratio, and increasing the argon pressure in the reduction vessel. This reduction was made on a $10 \mathrm{~g}$ scale. The charge was prepared with 0.75 mole of $I_{2}$ per mole of Am. The argon pressure left in the reduction vessel was increased to $7 \mathrm{psig}$. The reduction was made using a $\mathrm{MgO}$ crucible and crucible lid in a $15 \mathrm{~g}$-scale pressure vessel. The second charge reacted 4 minutes after the vessel was placed in the furnace, as indicated by a drop in the neutron flux from 18 to $2.2 \mathrm{mrem} / \mathrm{hr}$.
The underside of the pressure vessel lid was very clean when the vessel was opened. Some slag was found on the underside of the crucible lid and the top portion of the crucible. This indicated that some splattering had occurred, but it was very small compared to the first reduction. The button weighed $7.4 \mathrm{~g}$ for a $64.3 \%$ yield, but it had not coalesced well. The center of the button was well-formed, but the edges tended to break off easily. The decrease in the size of the charge and the $\mathrm{I}_{2}$ to Am ratio had greatly decreased the Am vaporization, but did not supply sufficient heat to provide a well-formed button.

The third reduction was also made on a $10 \mathrm{~g}$ scale, but the $I_{2}$ ratio was increased to 1 mole of $I_{2}$ per mole of Am. The argon pressure left in the reduction vessel following the purge was increased to $12 \mathrm{psig}$. The charge reacted 4 minutes after the vessel was placed in the furnace. The splattering was a little greater than that observed with the second reduction, but the button was very well-formed. The button weighed $5.50 \mathrm{~g}$ for a $52 \%$ yield.

The iodine ratio was decreased to 0.9 moles of $\mathrm{I}_{2} /$ mole of $\mathrm{Am}$ for the fourth reduction. The charge reacted after 5 minutes of heating. The button (see Figure 6) 


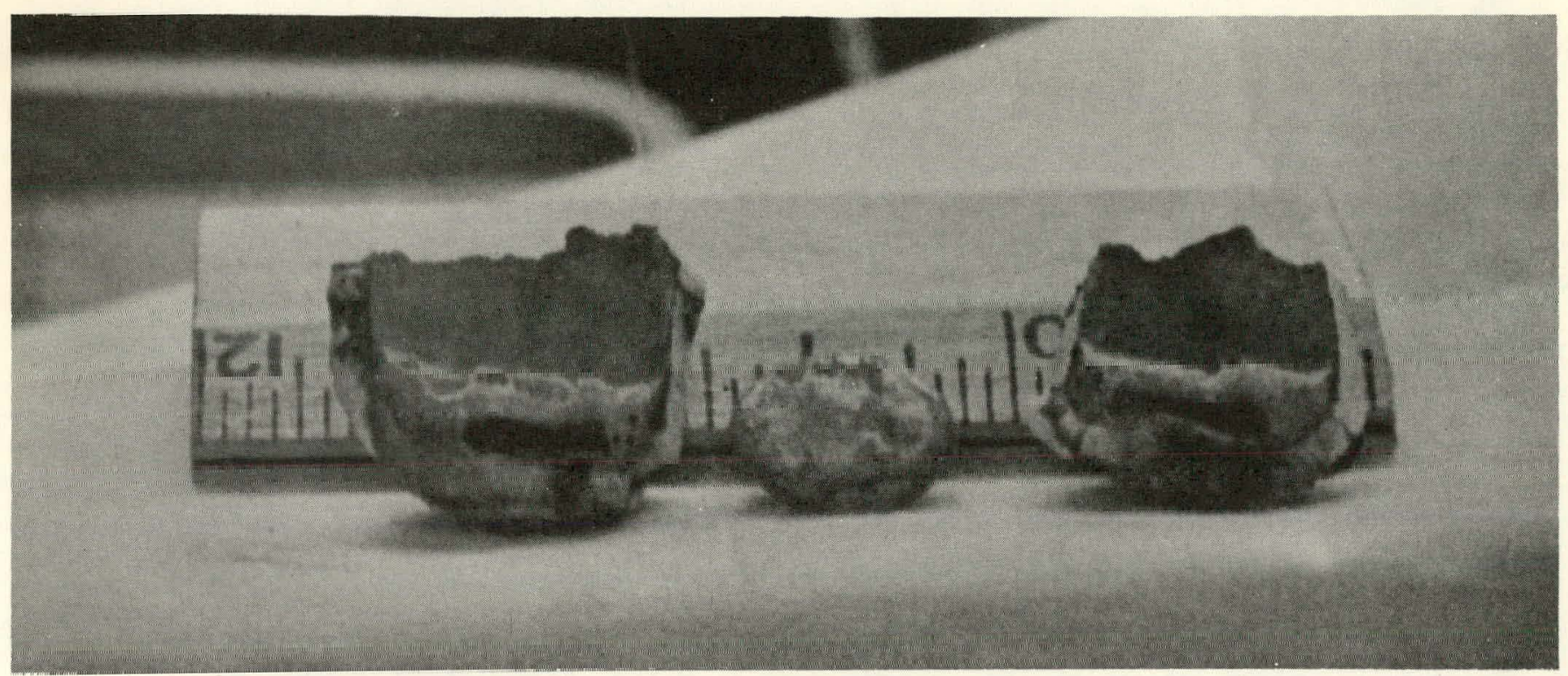

Figure 6. Americium button No. 4, slag and lower portion of $\mathrm{MgO}$ crucible.

weighed $5.0 \mathrm{~g}$ for a $47.2 \%$ yield. A summary of the reduction conditions and results is given in Table II.

Analytical Data: A comparison of the impurities in the $\mathrm{AmO}_{2}$ and buttons produced from the oxide is given in Table III. The buttons, with the exception of button number 1 , contained less impurities than the oxide. The first button contained large amounts of $\mathrm{Cr}, \mathrm{Cu}, \mathrm{Fe}$, and $\mathrm{Ni}$ because of attack on the pressure vessel and gasket caused by the excessive splattering. The impurities in the last 3 buttons were less than the impurities in the $\mathrm{AmO}_{2}$ as the result of a decrease in $\mathrm{Ca}, \mathrm{Ce}$ and, in the case of the second button, $\mathrm{Si}$. All three buttons picked up $\mathrm{Mg}$ from the $\mathrm{MgO}$ crucible. The Ta crucible appears to be superior to the
$\mathrm{MgO}$ crucible in this respect. Tantalum crucibles will probably be required to produce very pure Am metal.

Immersion densities and hardness were obtained for the third and fourth buttons. The density of the third button was $13.0807 \mathrm{~g} / \mathrm{cc}$ at $26.1^{\circ} \mathrm{C}$ and the density of the fourth button was $12.3539 \mathrm{~g} / \mathrm{cc}$ at $26.2^{\circ} \mathrm{C}$. These values agree fairly well with the reported density of $13.67 \mathrm{~g} / \mathrm{cc}$ at $20^{\circ} \mathrm{C}^{8}$ for Am metal, considering the large number of impurities present. The Rockwell hardness of the third button was E-82 and the Rockwell hardness of the fourth button was E-90. These values convert to Diamond Pyramid hardness values of 83 and 99, respectively. The Diamond Pyramid hardness of fully annealed delta plutonium is 44 .

Table II. Summary of americium bomb reductions.

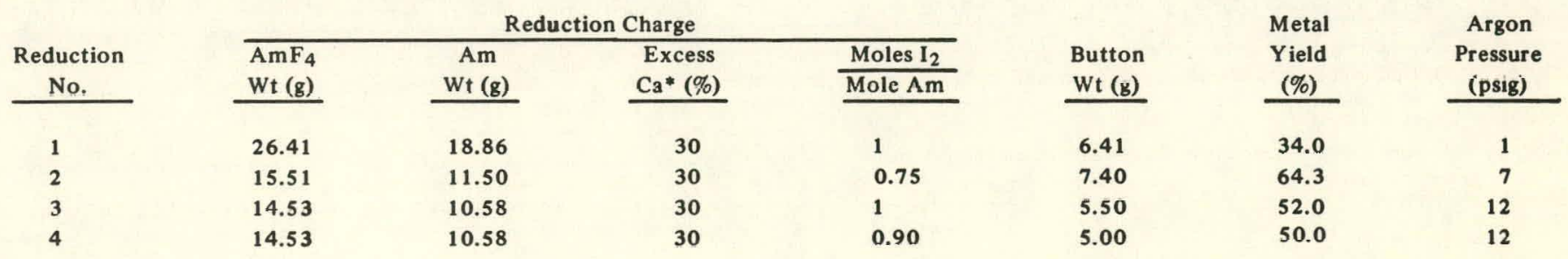

${ }^{*}$ Excess of $\mathrm{Ca}$ is the amount in excess of that stoichiometricaliy required to react with $\mathrm{AmF}_{4}$ and $\mathrm{I}_{2}$ present in the charge. 
RFP-1 188

Table III. Spectrographic analysis of $\mathrm{AmO}_{2}$ and Am.*

\begin{tabular}{|c|c|c|}
\hline \multirow{2}{*}{ Element } & \multicolumn{2}{|c|}{ Batch No. 1} \\
\hline & $\overline{\mathrm{AmO}_{2}}$ & $\mathrm{Am}$ \\
\hline $\mathrm{Al}$ & 1,000 & 1,000 \\
\hline B & 20 & $<1$ \\
\hline $\mathrm{Ba}$ & 20 & $<10$ \\
\hline $\mathrm{Be}$ & 1 & 2 \\
\hline $\mathrm{Ca}$ & 5,000 & 1,000 \\
\hline $\mathrm{Ce}$ & 10,000 & 10,000 \\
\hline $\mathrm{Cr}$ & 100 & 2,000 \\
\hline $\mathrm{Cu}$ & 20 & 5,000 \\
\hline $\mathrm{Fe}$ & 1,000 & 5,000 \\
\hline $\mathrm{Ga}$ & 50 & $<10$ \\
\hline $\mathrm{Ge}$ & 100 & $<100$ \\
\hline $\mathrm{Mg}$ & 300 & 1,000 \\
\hline $\mathrm{Mn}$ & 100 & 300 \\
\hline Mo & $<10$ & $<10$ \\
\hline $\mathrm{Nd}$ & 500 & $<100$ \\
\hline $\mathrm{Ni}$ & 2,000 & 3,000 \\
\hline Pd & 200 & $<50$ \\
\hline Si & 500 & 100 \\
\hline $\mathrm{Ta}$ & $<100$ & 300 \\
\hline $\mathrm{Tm}$ & 500 & 500 \\
\hline $\mathrm{Y}$ & 3,000 & 4,000 \\
\hline $\mathbf{Y b}$ & 50 & 50 \\
\hline
\end{tabular}

\begin{tabular}{rr}
\multicolumn{2}{c}{ Batch No. 2} \\
\hline $\mathrm{AmO}_{2}$ & $\mathrm{Am}$ \\
100 & 100 \\
300 & 10 \\
$<10$ & $<10$ \\
50 & 100 \\
5,000 & 3,000 \\
2,000 & 1,000 \\
$<5$ & $<10$ \\
10 & 50 \\
500 & 3,000 \\
$<50$ & $<10$ \\
$<100$ & $<100$ \\
300 & 3,000 \\
50 & 50 \\
50 & $<10$ \\
$<100$ & $<100$ \\
500 & 300 \\
500 & 50 \\
3,000 & 300 \\
$<100$ & 300 \\
1,000 & 300 \\
500 & 200 \\
500 & 50 \\
\hline &
\end{tabular}

\begin{tabular}{|c|c|c|}
\hline \multicolumn{3}{|c|}{ Batch No. 3} \\
\hline $\mathrm{AmO}_{2}$ & Am No. 3 & Am No. 4 \\
\hline 200 & 500 & 200 \\
\hline$<1$ & 1,000 & 200 \\
\hline$<10$ & $<10$ & $<10$ \\
\hline 5 & 5 & 1 \\
\hline 10,000 & 1,000 & 500 \\
\hline 10,000 & 5,000 & 5,000 \\
\hline 50 & $<10$ & $<10$ \\
\hline 30 & 500 & 300 \\
\hline 100 & 500 & 100 \\
\hline$<10$ & $<10$ & 500 \\
\hline$<100$ & $<_{100}$ & $<100^{\circ}$ \\
\hline$<10$ & 2,000 & 2,000 \\
\hline 50 & 100 & 100 \\
\hline$<10$ & $<10$ & 300 \\
\hline$<_{100}$ & $<100$ & $<100$ \\
\hline 500 & 1,000 & 500 \\
\hline 50 & 100 & 50 \\
\hline 100$)$ & 2U0 & 30 \\
\hline$<100$ & $<100$ & $<100$ \\
\hline 500 & $<50$ & $<50$ \\
\hline 700 & 500 & 500 \\
\hline 500 & $<5$ & 50 \\
\hline
\end{tabular}

Total

Detectable

Impurities

24,461

33,252

14,410

11,920

22,785

12,305

9,631

*Impurities are given as $\mu \mathrm{g}$ impurity/g Am - only detectable impurities are listed.

\section{REFERENCES}

1. K. W. R. Johnson and J. A. Leary, "Preparation of Americium Metal," Los Alamos Scientific Laboratory Report LA-2922, 1963.

2. W. Z. Wade and T. Wolf, "Preparation of MacroAmounts of Pure Americium Metal," Lawrence Radiation Laboratory Report UCRL-14513, 1966.

3. E. H. Kobisk, Oak Ridge National Laboratory, Private Communication, February 1968.

4. F. L. Oetting and S. Gunn, J. Inorg. Nucl. Chem., Vol. 29, 2659, 1957.
5. M. Stacey, J. C. Tatlow and A. G. Sharpe, "Advances in Fluur ine Clıemistry," Vol. 2, p 175, Butterworths, London, 1961.

6. W. V. Conner, "Preparation of Isotopically Pure Plutonium-241 Metal," RFP-1007, Rocky Flats Division, The Dow Chemical Company, September 8, 1967.

7. S. C. Corniglia and B. B. Cunningham, J. Am. Chem. Soc., 77, 1502 (1955).

8. D. B. McWhan, B. B. Cunningham and J. C. Wallmann, J. Inorg. Nucl. Chem., 24, 1025 (1962). 